\title{
Inhibition of Enzyme Formation Following Infection of Escherichia coli with phage T2r ${ }^{+}$
}

\author{
By A. P. LEVIN AND K. BURTON \\ M.R.C. Cell Metabolism Research Unit, Department of Biochemistry, \\ University of Oxford
}

(Received 22 December 1960)

\begin{abstract}
SUMMARY
The synthesis of aspartate carbamyl transferase (ureidosuccinic synthetase), of dihydroorotic dehydrogenase and of alkaline phosphatase by a uracil-requiring strain of Escherichia coli, when the organisms were suspended in a minimal medium lacking uracil, was followed subsequent to infection of the cells with bacteriophage $\mathbf{T} 2 \mathbf{r}^{+}$or with ghosts of the bacteriophage particles. The results were compared with the synthesis of these enzymes in uninfected cells. Following infection, the formation of all three enzymes was halted. Supplementation of the medium with casein hydrolysate and tryptophan or with $0.01 \mathrm{M}-\mathrm{Mg}^{++}+10^{-3} \mathrm{M}$-spermine did not prevent the inhibition caused by bacteriophage infection.
\end{abstract}

\section{INTRODUCTION}

When Escherichia coli in logarithmic growth is infected with phage T2, the net synthesis of protein continues but at a linear rather than a logarithmic rate (Cohen, 1948). The majority of the protein synthesized appears to be phage protein or enzymes concerned with phage formation (Bessman, 1959; Sommerville, Ebisuzaki \& Greenberg, 1959; Kornberg, Zimmerman, Kornberg \& Josse, 1959; Keck, Mahler \& Fraser, 1960). Whether a cell infected by a lytic phage is capable of synthesizing protein not concerned directly with phage synthesis was examined earlier by Monod \& Wollman (1947) and by Benzer (1953). They found that $\beta$-galactosidase was not formed by these cells following the addition of the inducer, lactose. French \& Siminovitch (1955) also found that this enzyme was not formed following infection with phage ghosts. Sher \& Mallette (1954) also were unable to demonstrate the continued formation of the inducible lysine decarboxylase after addition of either phage $\mathbf{T} 2 \mathrm{r}^{+}$or phage ghosts. However, even under conditions where limited amounts of protein can be synthesized, bacteria are able to synthesize relatively large amounts of enzymes in response to the removal of a repressor substance for these enzymes from the medium (Gorini \& Maas, 1957; Vogel, 1957; Yates \& Pardee, 1957; Levin \& Magasanik, 1961). By using such a system, we have examined the effect of phage infection on the ability of Escherichia coli to synthesize the enzymes aspartate carbamyl transferase (ureidosuccinic synthetase), dihydroorotic dehydrogenase and alkaline phosphatase after removal of uracil and inorganic phosphate from the medium. These enzymes were chosen because under certain circumstances they appear to be essential for the formation of nucleic acid precursors. 


\section{METHODS}

Organism. Strain $\mathrm{B}_{39}$, a uracil-requiring mutant of Escherichia coli $\mathrm{B}$, obtained from Dr F. C. Neidhardt (Harvard Medical School, Boston, Mass., U.S.A.), was used in these studies.

Bacteriophage. Coli phage strain $\mathrm{T}^{2} \mathrm{r}^{+}$maintained in this laboratory was used as the infecting agent and as the source of phage ghosts. Phage $\mathrm{T} 2 \mathbf{r}^{+}$stocks were prepared from lysates of bacteria grown in the basal salts medium and were purified by the method of Hook et al. (1946).

The ghosts were prepared according to the procedure of Herriott \& Barlow (1957). The protein content of ghost suspensions and of the starting phage preparation were measured; the \% protein remaining in the ghost suspension multiplied by the phage titre was accepted as the ghost titre. The viable phage titre of the ghost suspension was less than $0.2 \%$ of the original phage titre and was less than $0.5 \%$ of the ghost titre.

Media. Bacterial cultures were maintained on agar slopes containing ( $\%, \mathrm{w} / \mathrm{v})$ : Tryptone, $1 \cdot 0$; yeast extract, $0.5 ; \mathrm{Na}_{2} \mathrm{HPO}_{4} .2 \mathrm{H}_{2} \mathrm{O}, 0.3 ; \mathrm{KH}_{2} \mathrm{PO}_{4}, 0 \cdot 1$; glucose, 0.5 ; agar, $2 \cdot 0$. The cultures were transferred to fresh medium at 2-week intervals.

The composition of the basal medium used for growing and infecting the bacteria was $(\%, \mathrm{w} / \mathrm{v}): \mathrm{NH}_{4} \mathrm{Cl}, \mathrm{0} \cdot 1 ; \mathrm{Na}_{2} \mathrm{HPO}_{4} .2 \mathrm{H}_{2} \mathrm{O}, 1 \cdot 05 ; \mathrm{KH}_{2} \mathrm{PO}_{4}, 0 \cdot 4.5 ; \mathrm{MgSO}_{4} \cdot \mathrm{H}_{2} \mathrm{O}, 0.01$; $\mathrm{NaCl}, 0 \cdot 1$. Glucose added to a final concentration of $0 \cdot 2 \%(\mathrm{w} / \mathrm{v})$ was used as the carbon and energy source; uracil when added to the medium was at $50 \mu \mathrm{g} . / \mathrm{ml}$.

When a medium lacking inorganic phosphate was desired 2-amino-2-hydroxymethylpropane-1:3-diol (tris) adjusted to $\mathrm{pH} 7 \cdot 4$ with $\mathrm{HCl}$ was used to buffer the medium. The final concentration of tris was $0 \cdot 1 \mathrm{M}$.

The phage particles were stored in a diluting fluid composed of $(\%, w / v): \mathrm{NaCl}$, $0.65 ; \mathrm{MgCl}_{2} .6 \mathrm{H}_{2} \mathrm{O}, 0.2$; gelatin, 0.07 .

Nutrient agar was used for performing phage assays according to the agar layer technique of Adams (1950).

Chemicals. Uracil and L-tryptophan were obtained from L. Light \& Co., L-dihydroorotic acid and tris buffer were obtained from Sigma Chemical Co., St Louis, Mo., U.S.A.; ureidosuccinic acid and paranitrophenylphosphate were obtained from British Drug Houses, Ltd, spermine tetrahydrochloride was obtained from Hofmann La Roche, Basle, Switzerland. Tryptone, yeast extract and casein hydrolysate were obtained from Oxo, Ltd. Dilithium carbamylphosphate was generously provided by Mr T. Gascoyne of this Department. All other chemicals were of reagent grade.

Preparation of suspensions of organisms. Escherichia coli $\mathbf{B}$, strain $\mathbf{B}_{39}$, was grown overnight at $37^{\circ}$ with forced aeration in the basal medium containing uracil. Fifteen $\mathrm{ml}$. of this culture were used to inoculate $600 \mathrm{ml}$. fresh medium of the same composition, and the culture was then grown for three to four generations under similar conditions. The organisms, which were growing logarithmically, were centrifuged down, washed twice with basal salts medium and then resuspended in one-half to threequarters of the initial volume of basal medium. The viable counts of these suspensions were from $8 \times 10^{8}$ to $2 \times 10^{9} \mathrm{organisms} / \mathrm{ml}$. Portions $(25 \mathrm{ml}$.) of these suspensions were distributed into $100 \mathrm{ml}$. Erlenmeyer flasks and after the flasks were placed in a water bath at $37^{\circ}$, the cultures were incubated with forced aeration for the desired length of time and with the necessary additions. For the studies on alkaline phosphatase for- 
mation, organisms were washed and resuspended in the tris buffer medium; subsequent steps were as described above.

Preparation of enzyme extracts and determination of activities. Portions (20-25 ml.) of culture were centrifuged, the deposit washed with cold distilled water and then resuspended in 5.0 ml. cold water. The suspension was then disrupted for 4-5 min. in a $19 \mathrm{kc}$. $60 \mathrm{~W}$. sonic oscillator (Mullard-Measuring and Scientific Equipment Ltd., London). This preparation was then centrifuged for $5 \mathrm{~min}$. at $12,000 \mathrm{~g}$ and at $0-5^{\circ}$ in an International refrigerated centrifuge. The supernatant solution was decanted and tested for its aspartate carbamyl transferase and dihydroorotic dehydrogenase activities by the procedures of Yates \& Pardee (1957). Extracts for the determination of alkaline phosphatase activity were prepared and tested according to the procedure of Torriani (1960). Protein was measured by the method of Lowry, Rosebrough, Faar \& Randall (1951).

\section{RESULTS}

\section{Aspartate carbamyl transferase}

Yates \& Pardee (1957) demonstrated rapid synthesis of aspartate carbamyl transferase by uracil-requiring auxotrophs following exhaustion of uracil from the medium in which the organisms had been growing. When Escherichia coli B, strain $\mathbf{B}_{39}$, was incubated in basal medium lacking uracil, there was an increase with time in the enzymic activity of the cell extracts. This increase in activity depended on the presence of a source of nitrogen in the basal medium (Fig. 1, curve A). More rapid synthesis of enzyme occurred following the addition of amino acids in the form of casein hydrolysate + tryptophan than occurred after the addition of the simple nitrogen source $\mathrm{NH}_{4} \mathrm{Cl}$ (Fig. 1, curves $\mathrm{E}$ and B).

\section{Table 1. Aspartate carbamyl transferase activity of extracts from uninfected and infected cells of Escherichia coli $\boldsymbol{B}$, strain $\boldsymbol{B}_{\mathbf{3 9}}$}

62.5 $\mu \mathrm{g}$. of protein of an extract prepared from uninfected cells was used in $\mathbf{A}$ and $\mathbf{C}$. $72.5 \mu \mathrm{g}$. of protein of an extract from infected cells was used in B and C. The reaction mixtures were incubated for $60 \mathrm{~min}$. at $25^{\circ}$. The activity in $\mathrm{C}$ was $92.5 \%$ of the sum of the activities of $\mathbf{A}$ and $\mathbf{B}$.

$\begin{array}{lcc}\text { Extract } & \begin{array}{c}\text { Ureidosuccinic acid } \\ \text { formed } \\ (\mu \mathrm{mole})\end{array} \\ \text { A. Uninfected cells } & \mathbf{5 \cdot 7} \\ \text { B. Infected cells } & \mathbf{2 \cdot 4} \\ \text { C. A+B } & \mathbf{7 \cdot 5}\end{array}$

The effect of phage T2r+ on the synthesis of the enzyme is shown also in Fig. 1. Addition of phage $\mathrm{T}^{2} \mathrm{r}^{+} \mathbf{5}$ min. after suspending the organisms in uracil-free medium prevented the continued synthesis of enzyme normally found in uninfected cultures. This complete inhibition could be demonstrated despite different rates of synthesis proceeding at the time of infection (Fig. 1, curves D and G). Attempts to increase the rate of enzyme synthesis at the time of infection also failed to prevent the complete inhibition (Fig. 1, curve $C_{1}$ compared with curve $D$ ). The addition of ghosts also caused a complete inhibition of enzyme synthesis (Fig. 1, curves $C_{2}$ and F).

The possibility that phage infection prevented the appearance of increased activity of extracts by causing the production of an inhibitor of enzyme action, rather than by 
causing an inhibition of enzyme formation, proved unlikely since it was found that the addition of an extract from infected organisms to an extract from uninfected organisms changed only slightly the activity of the total preparation as compared with the sum of the two separate activities (Table 1 ).

That phage infection of Escherichia coli $\mathbf{B}$, strain $\mathrm{B}_{39}$, caused the formation of uracil, just as phage infection of $E$. coli, strain $15 \mathbf{T}^{-}$, caused the formation of thymine (Barner $\&$ Cohen, 1954), and that the uracil formed subsequently prevented the synthesis of the enzyme appeared unlikely since no change occurred in the total number of infective centres in a culture of $E$. coli $\mathbf{B}$, strain $\mathbf{B}_{39}$, infected in the absence of uracil and incubated for $95 \mathrm{~min}$. (Fig. 2).

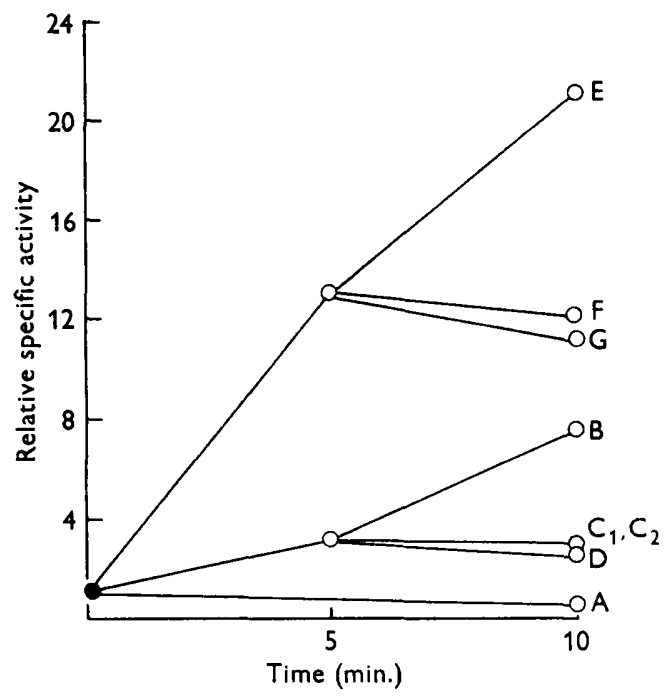

Fig. 1

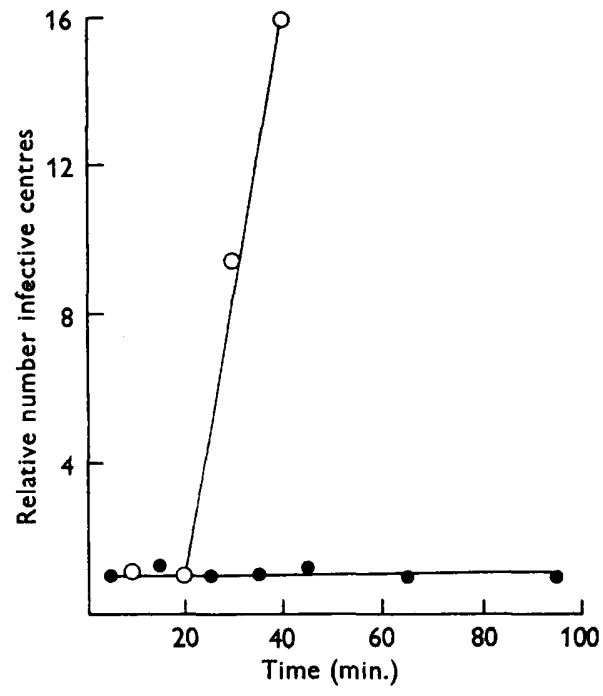

Fig. 2

Fig. 1. The effect of nitrogen sources, bacteriophage and ghosts on aspartate carbamyl transferase formation in Escherichia coli $\mathbf{B}$, strain $\mathbf{B}_{39}$. The values plotted are the specific activities of extracts relative to zero time. Specific activities are the $\mu$ mole ureidosuccinic acid formed/mg. protein $/ \mathrm{hr}$. Curves : $\mathrm{A}$, no nitrogen source added; $\mathrm{B}, \mathrm{NH}_{4} \mathrm{Cl}(0 \cdot 2 \%)$ added at zero time; $\mathrm{C}_{1}, \mathrm{~T} 2 \mathrm{r}^{+}$, casein hydrolysate $(0 \cdot 2 \%, \mathrm{w} / \mathrm{v})+\operatorname{tryptophan}(0 \cdot 1 \%, \mathrm{w} / \mathrm{v})$ added at 5 min.; $C_{2}$, ghosts added at 5 min.; $D$, phage $\mathbf{T}_{2} r^{+}$added at 5 min.; $E$, casein hydrolysate $(0.2 \%, w / v)+\operatorname{tryptophan}(0 \cdot 1 \%, w / v)$ added at zero time; $\mathbf{F}$, ghosts added at 5 min.; $G$, phage ${\mathrm{T} 2 \mathrm{r}^{+}}$added at $5 \mathrm{~min}$. The multiplicities of infection were: $\mathrm{C}_{1}, 4.7 ; \mathrm{C}_{2}, 6.0$; $\mathrm{D}, \mathbf{7 \cdot 9} ; \mathrm{F}, \mathbf{2} \cdot 4 ; \mathrm{G}, \mathbf{3 . 9}$.

Fig. 2. The total number of infective centres of phage $\mathrm{T} 2 \mathrm{r}^{+}$relative to the number added to a culture of Escherichia coli $\mathbf{B}$, strain $\mathbf{B}_{39^{*}}$ ( $(0)$, No uracil in the medium; (O), uracil added. Bacterial count $=1 \cdot 6 \times 10^{6}$ organisms $/ \mathrm{ml}$. Multiplicity of infection, $0 \cdot 01$. For other details of procedure see Burton (1955).

High multiplicities of infection can cause cell lysis (Delbrück, 1940) and thus release repressor molecules into the medium. Therefore, a medium was chosen in which one might expect the degree of cell lysis to be lower and consequently in which one might expect the apparent inhibition of enzyme formation caused by bacteriophage infection to be prevented. Infection was carried out in a medium containing $0.01 \mathrm{M}-\mathrm{Mg}^{++}$and in a medium containing $0.01 \mathrm{M}-\mathrm{Mg}^{++}+10^{-3} \mathrm{M}$-spermine. The addition of spermine to a basal medium has been shown to maintain spheroplasts of 
Escherichia coli (Mager, 1959). In neither case was synthesis of enzyme carried out (Fig. 3). The inhibition of enzyme formation in the medium containing $0.01 \mathrm{M}-\mathrm{Mg}^{++}$ remained complete for as long as $90 \mathrm{~min}$. (curve $\mathrm{E}$ ) despite the fact that no viable phage particles were formed during this period.

\section{Dihydroorotic dehydrogenase}

Dihydroorotic dehydrogenase also has been found to increase in pyrimidine auxotrophs maintained in the absence of uracil (Yates \& Pardee, 1957). The formation of this enzyme by infected and uninfected organisms of Escherichia coli $\mathbf{B}$, strain $\mathbf{B}_{\mathbf{3 9}}$, was examined; results similar to those found with aspartate carbamyl transferase were obtained (Table 2).

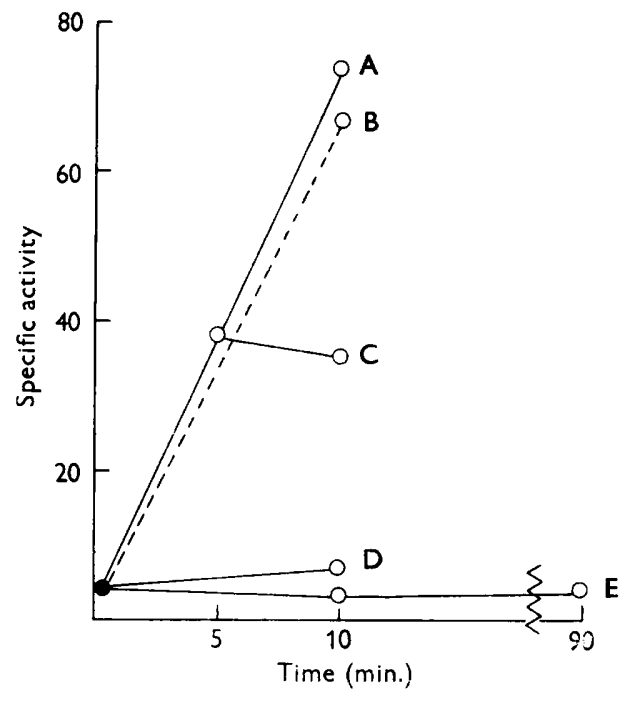

Fig. 3

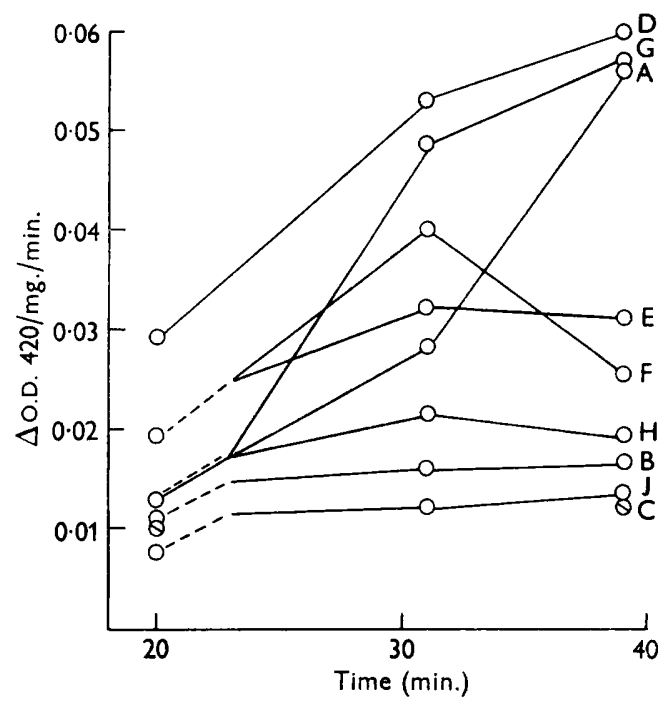

Fig. 4

Fig. 3. The effect of $\mathrm{Mg}^{++}$, spermine and phage $\mathrm{T}_{2} \mathrm{r}^{+}$on aspartate carbamyl transferase formation in Escherichia coli $\mathbf{B}$, strain $\mathbf{B}_{39}$. Curves: $\mathbf{A}=\mathrm{Mg}^{++}, 0.01 \mathrm{M} ; \mathbf{B}=\mathbf{A}+$ spermine $10^{-} 3 \mathrm{M}$, at zero time; $\mathrm{C}=\mathrm{A}$ with phage $\mathrm{T} 2 \mathrm{r}^{+}$added at $5 \mathrm{~min}$.; $\mathrm{D}=\mathrm{B}$ with phage $\mathrm{T} 2 \mathrm{r}^{+}$ added at zero time; $\mathbf{E}=\mathbf{A}$ with phage $\mathbf{T} 2 \mathbf{r}^{+}$added at zero time. The multiplicities of infection were $14 \cdot 2$ in curve $C$ and $17 \cdot 7$ in curves $D$ and $E$.

Fig. 4. Formation of alkaline phosphatase by Escherichia coli $\mathbf{B}$, strain $\mathbf{B}_{39}$.

Series 1 . Multiplicity of infection $=35 \cdot 8$; no addition at zero time. Curve $A$, no addition; curve $B$, phage $\mathbf{T} 2 \mathbf{r}^{+}$added; curve $\mathbf{C}$, phosphate added, two points only, $Q$.

Series 2. Multiplicity of infection $=25 \cdot 1$; uracil added at zero time. Curve $D$, no addition; curve $\mathrm{E}$, phage $\mathrm{T} 2 \mathrm{r}^{+}$added; curve $\mathrm{F}$, phosphate added.

Series 3. Multiplicity of infection $=32 \cdot 6$; no addition at zero time. Curve G, uracil added; curve $\mathrm{H}$, uracil + phage $\mathrm{T} 2 \mathrm{r}^{+}$added ; curve $J$, phosphate + uracil added.

Additions were made at $23 \mathrm{~min}$. The final concentration of phosphate was $80 \mu \mathrm{mole} / \mathrm{ml}$.; of uracil was $50 \mu \mathrm{g} . / \mathrm{ml}$.

\section{Alkaline phosphatase}

The synthesis of alkaline phosphatase was examined as another example and also because it is controlled by a different repressor, namely inorganic phosphate (Torriani, 1960). When organisms of Escherichia coli $\mathbf{B}$, strain $\mathbf{B}_{\mathbf{3 9}}$, were suspended in a medium which did not contain inorganic phosphate, it was found that the presence or 
absence of uracil did not markedly affect ability to make alkaline phosphatase enzyme (Fig. 4, curves A, D, G). The addition of inorganic phosphate (curves C, F, J) or phage $\mathbf{T} 2 \mathbf{r}^{+}$(curves $\mathrm{B}, \mathbf{E}, \mathbf{H}$ ) caused inhibition of enzyme formation. It was found also that ghosts of phage $\mathrm{T}_{2} \mathrm{r}^{+}$caused an inhibition of enzyme formation.

\section{Table 2. Dihydroorotic dehydrogenase activity in extracts from uninfected and infected cells of Escherichia coli $B$, strain $B_{39}$}

Organisms were suspended in basal medium with the additions noted in the table. The multiplicities of infection were $14 \cdot 2$ in $C$ and $17 \cdot 7$ in $B$ and $E$.

\begin{tabular}{|c|c|c|c|c|}
\hline & Additions & $\begin{array}{c}\text { Time of } \\
\text { addition of } \\
\text { T2 }{ }^{+} \\
\text {(min.) }\end{array}$ & $\begin{array}{l}\text { Time of } \\
\text { sampling } \\
\text { (min.) }\end{array}$ & $\begin{array}{c}\text { Orotic acid } \\
\text { formed } \\
(\mu \text { mole } / \mathrm{mg} . / \mathrm{hr} .)\end{array}$ \\
\hline \multirow[t]{3}{*}{ A. } & $\mathrm{Mg}^{++}, 10^{-2} \mathrm{M}$ & - & $\mathbf{0}$ & $\mathbf{5 \cdot 3}$ \\
\hline & & & $\mathbf{5}$ & $\boldsymbol{7 \cdot 9}$ \\
\hline & & & 10 & $11 \cdot 8$ \\
\hline B. & $\mathrm{Mg}^{++}, 10^{-2} \mathrm{M}$ & $\mathbf{0}$ & 10 & 4.5 \\
\hline C. & $\mathrm{Mg}^{++}, 10^{-2} \mathbf{M}$ & $\mathbf{5}$ & 10 & $6 \cdot 7$ \\
\hline D. & $\mathrm{Mg}^{++}, 10^{-2} \mathrm{M}+$ spermine, $10^{-3} \mathrm{M}$ & 一 & 10 & $11 \cdot 7$ \\
\hline E. & $\mathrm{Mg}^{++}, 10^{-2} \mathrm{M}+$ spermine, $10^{-\mathbf{8}} \mathbf{M}$ & $\mathbf{0}$ & 10 & $4 \cdot 1$ \\
\hline
\end{tabular}

\section{DISCUSSION}

Our results show that following infection with phage $\mathrm{T} 2 \mathrm{r}^{+}$or with phage ghosts, organisms of Escherichia coli $\mathrm{B}$, strain $\mathrm{B}_{39}$, did not synthesize certain enzymes, where the formation of the enzymes had been repressed by previous growth conditions, even though the repressors had been removed from the medium shortly before the infection. That the action of the phage in stopping the formation of host protein was due to a more favourable competition of the infecting system for available amino acids seems unlikely in view of the findings obtained here that supplementation of the infecting medium with amino acids did not prevent the inhibition of enzyme formation. A medium of greater osmotic pressure which might have decreased the loss of cell constituents into the medium also did not affect the inhibition of enzyme formation caused by phage infection. Although in some of the experiments presented, very small increases were seen in enzyme activity over those at the time of addition of the phage, these increased activities represented maximum values of 0.5-3 min. of continued synthesis based on the rate of synthesis of uninfected cells. The techniques used in the present work would not be able to detect whether synthesis actually continued after infection for these lengths of time, or whether there might have been a delay in the adsorption or penetration of phage, leading to small increases in the amount of enzyme.

The effects of ${ }^{32} \mathrm{P}$ decay on the viability of bacteria and on their ability to form enzymes have been interpreted as suggesting that intact deoxyribonucleic acid (DNA) is necessary for the synthesis of bacterial enzymes (McFall, Pardee \& Stent, 1958; Riley, Pardee, Jacob \& Monod, 1960). This hypothesis would provide a plausible explanation of the results observed here, since there is extensive breakdown of the host DNA following phage infection (Weed \& Cohen, 1951; Kozloff, Knowlton, Putnam \& Evans, 1951 ; Hershey, Dixon \& Chase, 1953; Burton, 1955). In another situation, McFall \& Magasanik (1960) found that alkaline phosphatase was formed in a thymine-deficient culture of Escherichia coli, strain $15 \mathrm{~T}^{-}$, when the synthesis of 
$\beta$-galactosidase and other proteins was inhibited. McFall \& Magasanik suggested that the inhibition of $\beta$-galactosidase synthesis was a result, not of irreversible nuclear damage, but of repression. The possibility that the enzymes we have studied are not formed because of an accumulation of endogenous repressor substances seems to be unlikely, because the enzymes are involved in the synthesis of the precursors of DNA which are normally utilized by the phage-infected cell at an enhanced rate. However, other mechanisms are possible; one is suggested by the observations of the effect of phage infection on the permeability of the cell (Puck \& Lee, 1954, 1955) and by the observation of Bessman \& van Bibber (1959) that guanine deoxynucleotide kinase synthesized after phage infection requires different activating metal ions from the host enzyme which catalyses the same reaction. It is possible that the synthesis of host protein has different ionic requirements from those of the synthesis of protein in the phage infected cell.

During this investigation one of us (A.P.L.) was a Fellow of The Jane Coffin Childs Memorial Fund for Medical Research; the investigation was aided by a grant from The Jane Coffin Childs Memorial Fund for Medical Research.

\section{REFERENCES}

Adams, M. H. (1950). Methods of study of bacterial viruses. Meth. med. Res. 2, 1.

BARNER, H. D. \& CoHEN, S. S. (1954). The induction of thymine synthesis by T2 infection of a thymine requiring mutant of Escherichia coli. J. Bact. 68, 80.

Benzer, S. (1953). Induced synthesis of enzymes in bacteria analyzed at the cellular level. Biochim. biophys. Acta, 11, 383.

Bessman, M. J. (1959). Deoxyribonucleotide kinases in normal and virus infected Escherichia coli. J. biol. Chem. 234, 2735.

Bessman, M. J. \& van Bibber, M. J. (1959). A change in the properties of deoxyguanylate kinase of $E$. coli caused by viral infection. Biochem. biophys. res. Comm. 1, 101.

Burton, K. (1955). The relation between the synthesis of deoxyribonucleic acid and the synthesis of protein in the multiplication of bacteriophage T2. Biochem. J. 61, 473.

CoHEN, S. S. (1948). The synthesis of bacterial viruses. I. The synthesis of nucleic acid and protein in Escherichia coli B infected with T2r ${ }^{+}$bacteriophage. J. biol. Chem. 174, 281.

Delbrück, M. (1940). The growth of bacteriophage and lysis of the host. J. gen. Physiol. 23, 643.

French, R. C. \& Siminovitch, L. (1955). The action of T2 bacteriophage ghosts on Escherichia coli B. Canad. J. Microbiol. 1, 757.

GoRINI, L. \& MAAS, W. (1957). The potential for the formation of a biosynthetic enzyme in Escherichia coli. Biochim. biophys. Acta, 25, 208.

Herriott, R. M. \& Barlow, J. L. (1957). The protein coats or 'ghosts' of coliphage T2. I. Preparation, assay and some chemical properties. J. gen. Physiol. 40, 809.

Hershey, A. D., Dixon, J. D. \& Chase, M. (1953). Nucleic acid economy in bacteria infected with bacteriophage T2. I. Purine and pyrimidine composition. J. gen. Physiol. 36, 777.

Hook, A. E., Beard, D., Taylor, A. R., Sharp, D. G. \& Beard, J. W. (1946). Isolation and characterization of the T2 bacteriophage of Escherichia coli. J. biol. Chem. 165, 241.

Keck, K., Mahler, H. R. \& Fraser, D. (1960). Synthesis of deoxycytidine 5'-phosphate deaminase in Escherichia coli infected by T2 bacteriophage. Arch. Biochem. Biophys. 86, 85.

Kornberg, A., Zimmerman, S. B., Kornberg, S. R. \& Josse, J. (1959). Enzymatic synthesis of deoxyribonucleic acid. VI. Influence of bacteriophage $T_{2}$ on the synthetic pathway in host cells. Proc. nat. Acad. Sci., Wash. 45, 772. 
Kozloff, L. M., Knowlton, K., Putnam, F. W. \& Evans, E. A. (1951). Biochemical studies of virus reproduction. V. The origin of bacteriophage nitrogen. J. biol. Chem. $188,101$.

Levin, A. P. \& Magasanik, B. (1961). The effect of purines on the formation of two enzymes involved in purine biosynthesis. J. biol. Chem. 236, 184.

Lowry, O. H., Rosebrough, N. J., FAar, A. L. \& Randall, R. J. (1951). Protein measurement with the Folin reagent. J. biol. Chem. 193, 265.

MAGER, J. (1959). The stabilizing effect of spermine and related polyamines and protoplasts. Biochim. biophys. Acta, 36, 529.

McFall, E., Pardee, A. B. \& Stent, G. S. (1958). The effects of radiophosphorous decay on some synthetic capacities of bacteria. Biochim. biophys. Acta, 27, 282.

MCFALL, E. \& MAGaSANIK, B. (1960). Thymine starvation and enzyme synthesis. Biochim. biophys. Acta, 45, 610.

Monod, J. \& Wolluman, E. (1947). L'inhibition de la croissance et de l'adaptation enzymatique chez les bactéries infectées par le bacteriophage. Ann. Inst. Pasteur, 73, 937.

Puck, T. T. \& LEE, H. H. (1954). Mechanism of cell wall penetration by viruses. I. An increase in host cell permeability induced by bacteriophage infection. J. exp. Med. 99, 481.

Puck, T. T. \& LeE, H. H. (1955). Mechanism of cell wall penetration by viruses. II. Demonstration of cyclic permeability change accompanying virus infection of Escherichia coli B. cells. J. exp. Med. 101, 151.

Riley, M., Pardee, A. B., Jacob, F. \& Monod, J. (1960). On the expression of a structural gene. J. mol. Biol. 2, 216.

Sher, I. H. \& Mallette, M. F. (1954). The adaptive nature of the formation of lysine decarboxylase in Escherichia coli B. Arch. Biochem. Biophys. 52, 331.

Sommerville, R., Ebisuzaki, K. \& Greenberg, G. R. (1959). Hydroxymethyldeoxycytidylate kinase formation after bacteriophage infection of Escherichia coli. Proc. nat. Acad. Sci., Wash. 45, 1240.

Torriani, A. M. (1960). Influence of inorganic phosphate in the formation of phosphatases by Escherichia coli. Biochim. biophys. Acta, 38, 460 .

VoGEL, H. J. (1957). Repression and induction as control mechanisms of enzyme biogenesis: The 'adaptive' formation of acetylornithinase. In The Chemical Basis of Heridity, p. 276. Ed. W. D. MeElroy and B. Glass, Baltimore, Md. U.S.A.: The Johns Hopkins Press.

Weed, L. L. \& Cohen, S. S. (1951). The utilization of host pyrimidines in the synthesis of bacterial viruses. J. biol. Chem. 192, 693.

Yates, R. A. \& PARdee, A. B. (1957). Control by uracil of formation of enzymes required for orotate synthesis. J. biol. Chem. 227, 677 . 